\title{
Thousands of pregnant women in Puerto Rico are at risk of Zika virus infection, CDC warns
}

\author{
Michael McCarthy
}

Seattle

The number of Zika virus infections was increasing rapidly on the island of Puerto Rico, putting thousands of pregnant women at risk of infection, the director of the US Centers for Disease Control and Prevention (CDC), Tom Frieden, said in a teleconference with reporters on 17 June.

"This could lead to dozens or hundreds of infants being born with microcephaly in the coming year. For the thousands of other infants born to women infected with Zika who don't have microcephaly we simply don't know, and may not know for years, if there will be long term consequences on brain development," Frieden said.

Frieden made his comments after the CDC published Zika virus screening results ${ }^{1}$ of nearly 13000 blood donations made from 3 April until 11 June. Overall 68 (0.5\%) donors were viremic and the percentage who tested positive for the virus was growing, reaching $1.1 \%$ in the last week of the study period.

Although the blood donation population was not statistically representative of the general population, the increasing prevalence of Zika virus in donor blood reflected an overall

increase in the incidence of infection at large, CDC officials said.

They said that when chikungunya virus-which is spread by the same mosquito as Zika-was introduced to Puerto Rico in 2014 , screening suggested that nearly $25 \%$ of the population of Puerto Rico had become infected.

Frieden said that the CDC was working with the Puerto Rico health department to expand mosquito control efforts and to promote measures that individuals could take to reduce their risk of infection, such as using insect repellent. "We can't make that risk zero," Frieden said, "but even if we can reduce it by $10 \%$ or $30 \%$ or $50 \%$, that is a significant number of tragedies that we can prevent and we're doing everything we can to do that."

1 Kuehnert MJ, Basavaraju SV, Moseley RR, et al. Screening of blood donations for Zika virus infection: Puerto Rico, April 3-June 11, 2016. Morb Mortal Wkly Rep 2016.10.15585/ mmwr.mm6524e2.

Published by the BMJ Publishing Group Limited. For permission to use (where not already granted under a licence) please go to http://group.bmj.com/group/rights-licensing/ permissions 